\title{
GALLS AND GALL MAKERS IN PLANTS FROM THE PÉ-DE-GIGANTE CERRADO RESERVE, SANTA RITA DO PASSA QUATRO, SP, BRAZIL
}

\author{
URSO-GUIMARÃES, M. V. ${ }^{1}$ and SCARELI-SANTOS, C. ${ }^{2}$ \\ ${ }^{1}$ UFSCar/Campus Sorocaba, Avenida Darci Carvalho Daffner, 200, \\ Alto da Boa Vista, CEP 18085-850, Sorocaba, SP, Brazil \\ ${ }^{2}$ Centro de Investigaciones en Ecosistemas, Instituto de Ecología, UNAM, \\ Campus Morelia Antigua Carretera a Pátzcuaro, 8701, Col. Ex-Hacienda de San José de la Huerta, \\ C. P. 58190, Morelia, Michoacán, México \\ Correspondence to: Maria Virginia Urso-Guimarães, UFSCar/Campus Sorocaba, \\ Avenida Darci Carvalho Daffner, 200, Alto da Boa Vista, CEP 18085-850, Sorocaba, SP, Brazil, \\ e-mail: virginia@power.ufscar.br \\ Received June 24, 2004 - Accepted October 15, 2004 - Distributed February 28, 2006
}

(With 32 figures)

\begin{abstract}
Thirty-six morphologically different types of galls were obtained in leaves, leaflets, veins, petioles, stems, tendrils and flower buds from twenty-five species of plants in the Pé-de-Gigante Reserve, municipality of Santa Rita do Passa Quatro, state of São Paulo, Brazil. The host plant species belong to the closely related families Anacardiaceae, Annonaceae, Asteraceae, Bignoniaceae, Caryocaraceae, Erythroxylaceae, Fabaceae, Malpighiaceae, Melastomataceae, Myrtaceae, Ochnaceae, Polygalaceae, Sapindaceae, Sapotaceae, and Smilacaceae. The most common gall makers included Cecidomyiidae (Diptera), Pteromalidae (Hymenoptera) and Diaspididae (Sternorrhyncha-Hemiptera). This is the first report of galls found in the following plant genera: Gochnatia (Asteraceae), Distictela (Bignoniaceae), Banisteriopsis (Malpighiaceae), Ouratea (Ochnaceae), and Bredemeyera (Polygalaceae). The results of this work contribute to the body of knowledge about the relationship among host plants, gall makers, and the gall morphology of Pé-de-Gigante Cerrado Reserve.
\end{abstract}

Keywords: Cecidomyiidae, cerrado, gall, gall maker.

\section{RESUMO}

\section{Galhas e galhadores em plantas da Reserva de Cerrado Pé-de-Gigante, Santa Rita do Passa Quatro, SP, Brasil}

Trinta e seis diferentes tipos morfológicos de galhas foram obtidos em folhas, foliólulos, nervuras, pecíolos, ramos e inflorescências de vinte e cinco espécies de plantas na Reserva de Cerrado Pé-de-Gigante, Município de Santa Rita do Passa Quatro, SP, Brasil. As plantas hospedeiras pertencem às famílias: Anacardiaceae, Annonaceae, Asteraceae, Bignoniaceae, Caryocaraceae, Erythroxylaceae, Fabaceae, Malpighiaceae, Melastomataceae, Myrtaceae, Ochnaceae, Polygalaceae, Sapindaceae, Sapotaceae e Smilacaceae. Entre as famílias dos insetos galhadores foram observados Cecidomyiidae (Diptera), Pteromalidae (Hymenoptera) e Diaspididae (Sternorrhyncha-Hemiptera). Este é o primeiro relato da presença de galhas em plantas dos seguintes gêneros: Gochnatia (Asteraceae), Distictela (Bignoniaceae), Banisteriopsis (Malpighiaceae), Ouratea (Ochnaceae) e Bredemeyera (Polygalaceae). Os resultados deste trabalho contribuem para o aumento do conhecimento das relações entre plantas hospedeiras e galhadores e da morfologia das galhas da Reserva de Cerrado Pé-de-Gigante.

Palavras-chave: Cecidomyiidae, cerrado, galha, galhador. 


\section{INTRODUCTION}

Different gall makers can attack the same vegetal species, causing the reorganization of species-specific characteristics (Hartley, 1998). The manipulation of the host plant by a gall maker can be so great that the latter assumes control of the gall tissue's chemical composition, which can be quite different from the ungalled tissue (ScareliSantos, 2001). Some authors have commented on the high level of specificity of gall makers and host plant association (Mani, 1964; Abrahamson \& Weiss, 1987).

Although gall inducers belong to many different taxa, the gall makers induce galls in relatively few plant groups, and each one is closely related with the host. According to Abrahamson \& Weiss (1987), 87\% of all cynipids attack specifically certain species of Quercus (Fagaceae). Cynipid (Cynipini, Hymenoptera) - oak (Quercus spp., Fagaceae) interaction is a kind of association that Brooks \& McLennan (1991) called association by descent or coevolution. This kind of relationship is well known in the Nearctic region, but its study is still incipient in the Neotropical region because gall maker-host plant systems and the relationships between them are only just beginning.
This paper focuses on the determination of the relationship between host plants and gall makers from the Pé-de-Gigante Cerrado Reserve, characterizing the gall morphology, which is very specific to each host plant-gall maker.

\section{MATERIAL AND METHODS}

\section{Sampling area}

Samples were collected in the Pé-de-Gigante Cerrado Reserve, situated in the municipality of Santa Rita do Passa Quatro, SP, southeastern Brazil (Fig. 1), from 1996 through 2001. The site's geographical coordinates are: $21^{\circ} 35^{\prime} \mathrm{S}$ and $47^{\circ} 35^{\prime}$ W. Samples were collected monthly from 1997 to 1998 and at irregular intervals during the other years. The reserve is situated in the Santa Rita mountains at an altitude of 590 to $740 \mathrm{~m}$.

About $98 \%$ of the reserve is covered by Cerrado (savanna-like vegetation) with varying physiognomies (Batalha \& Mantovani, 2000), which were studied by Pivello et al. (1999) based on Landsat-TM satellite images (Fig. 2).

\section{Treatment of samples}

The samples were treated as described by Fernandes et al. (1988). Cecidomiids were

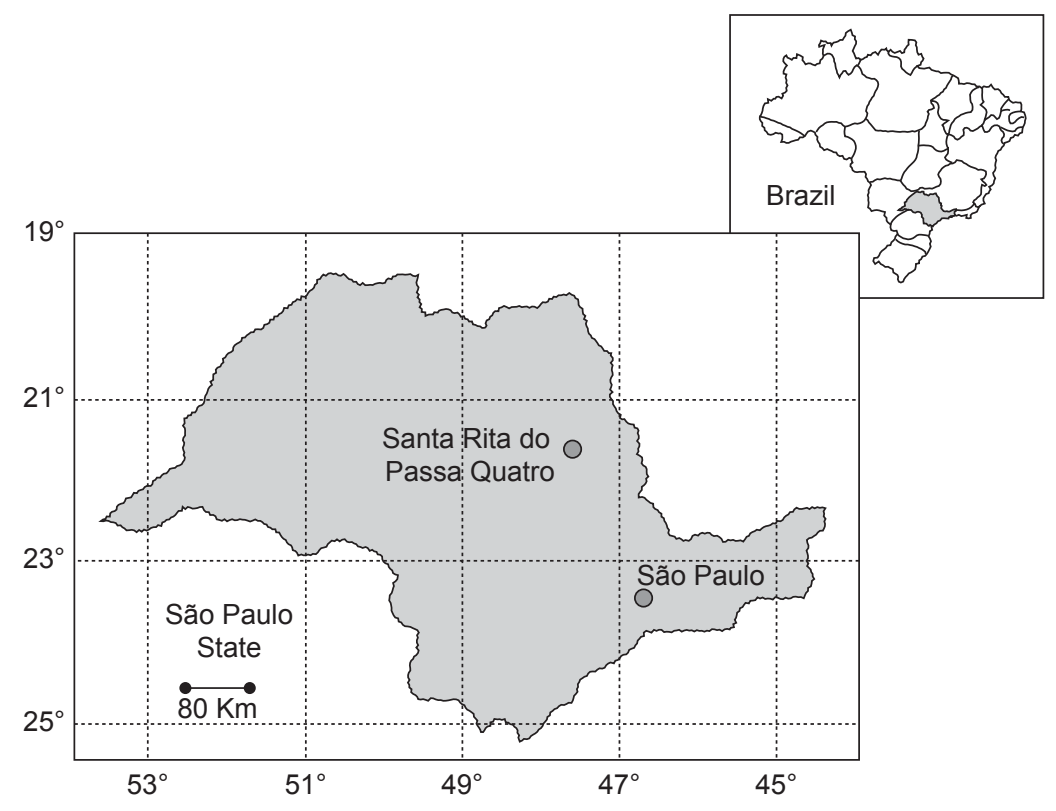

Fig. 1 - Location of the municipality of Santa Rita do Passa Quatro, SP, Brazil (Sallis et al., 1995 apud Batalha, 1997). 


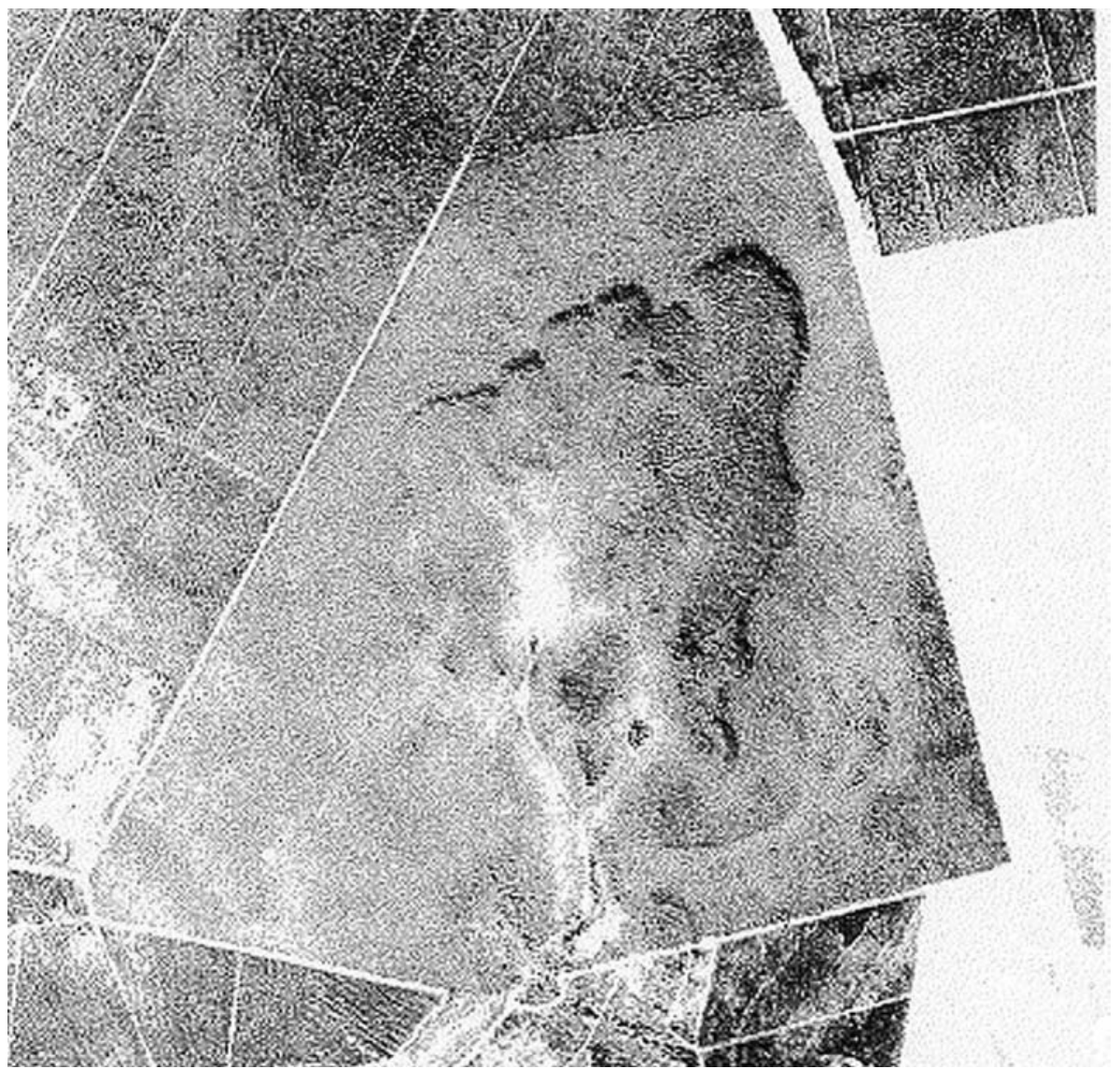

Fig. 2 - Aerial view of Pé-de Gigante Cerrado Reserve, Santa Rita do Passa Quatro, SP, Brazil (Source: Pivello et al., 1999).

identified using keys to immatures of the Nearctic Region (Gagné, 1989), and immatures and adults of the Neotropical region (Gagné, 1994). Vouchers of host plants were deposited in the Botanical Section and galls and insects in the Laboratory of Diphthera at the University of São Paulo Faculty of Philosophy, Sciences and Letters Department of Biology in Ribeirão Preto, SP, Brazil.

All the specimens were given a registration number (RN) which is listed in Appendix. The names and distribution of the plant species were looked up in Lorenzi's book (1992) and/or on the homepage of the Missouri Botanical Garden's VAST (VAScular Tropicos) database at: http://mobot.mobot.org/W3T/Search/vast. html. Urso-Guimarães \& Scareli-Santos are the authors of the gall pictures presented in this paper.

\section{RESULTS AND DISCUSSION}

Table 1 provides information about the relationship between host plants and gall makers of each gall type, while Table 2 lists information on the gall morphology of each host plant. Appendix contains data on the samples and additional information. The galls are featured in Figs. 3 to 32 .

\section{Plant Hosts and Galls of the Pé-de-Gigante Cerrado Reserve}

As mentioned earlier herein, morphologically dissimilar galls are frequently found in the same plant species. In the Pé-de-Gigante reserve, Duguetia furfuracea (A. St.-Hil.) Benth. \& Hook. f. (Figs. 4-6) and Myrcia bella Cambess. (Figs. 23-26) presented three types of galls, while 


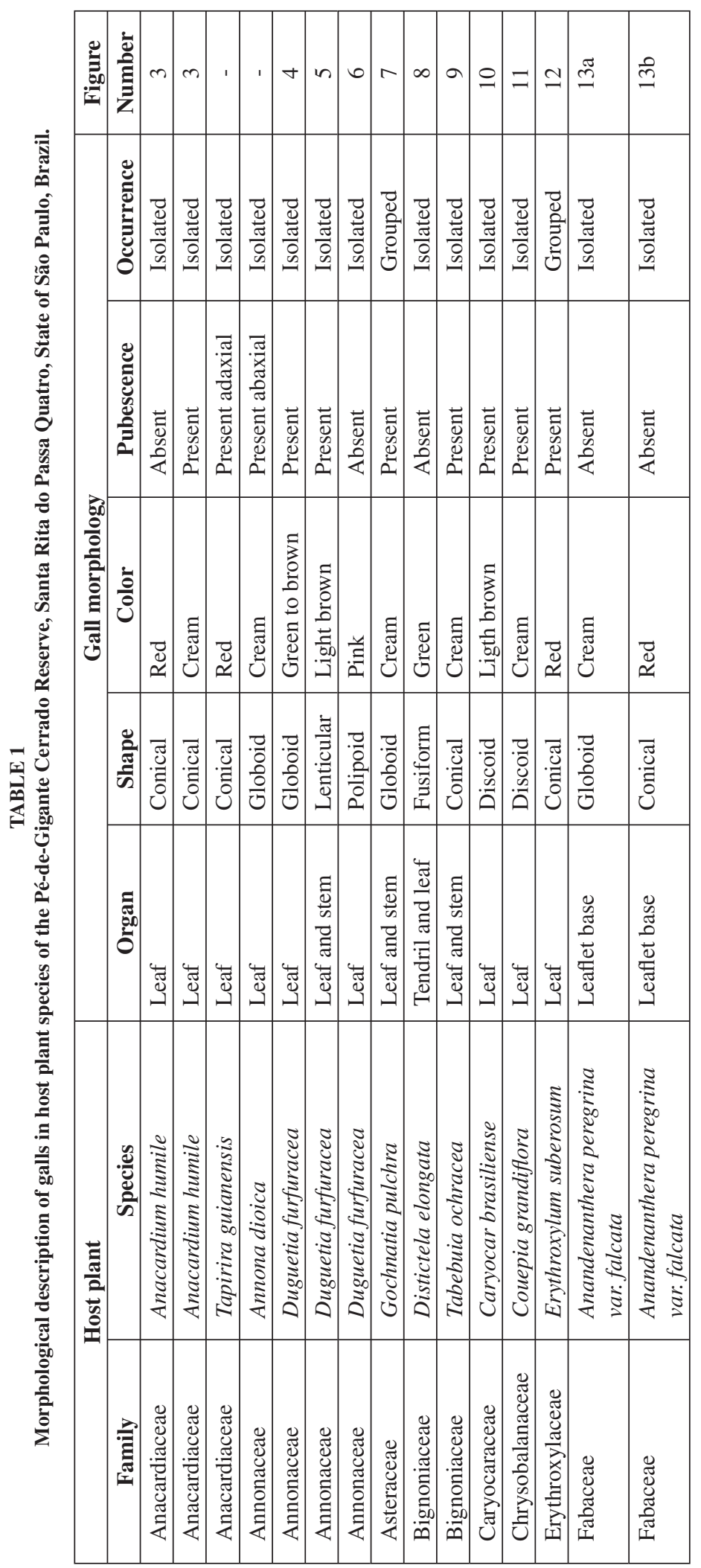

Braz. J. Biol., 66(1B): 357-369, 2006 


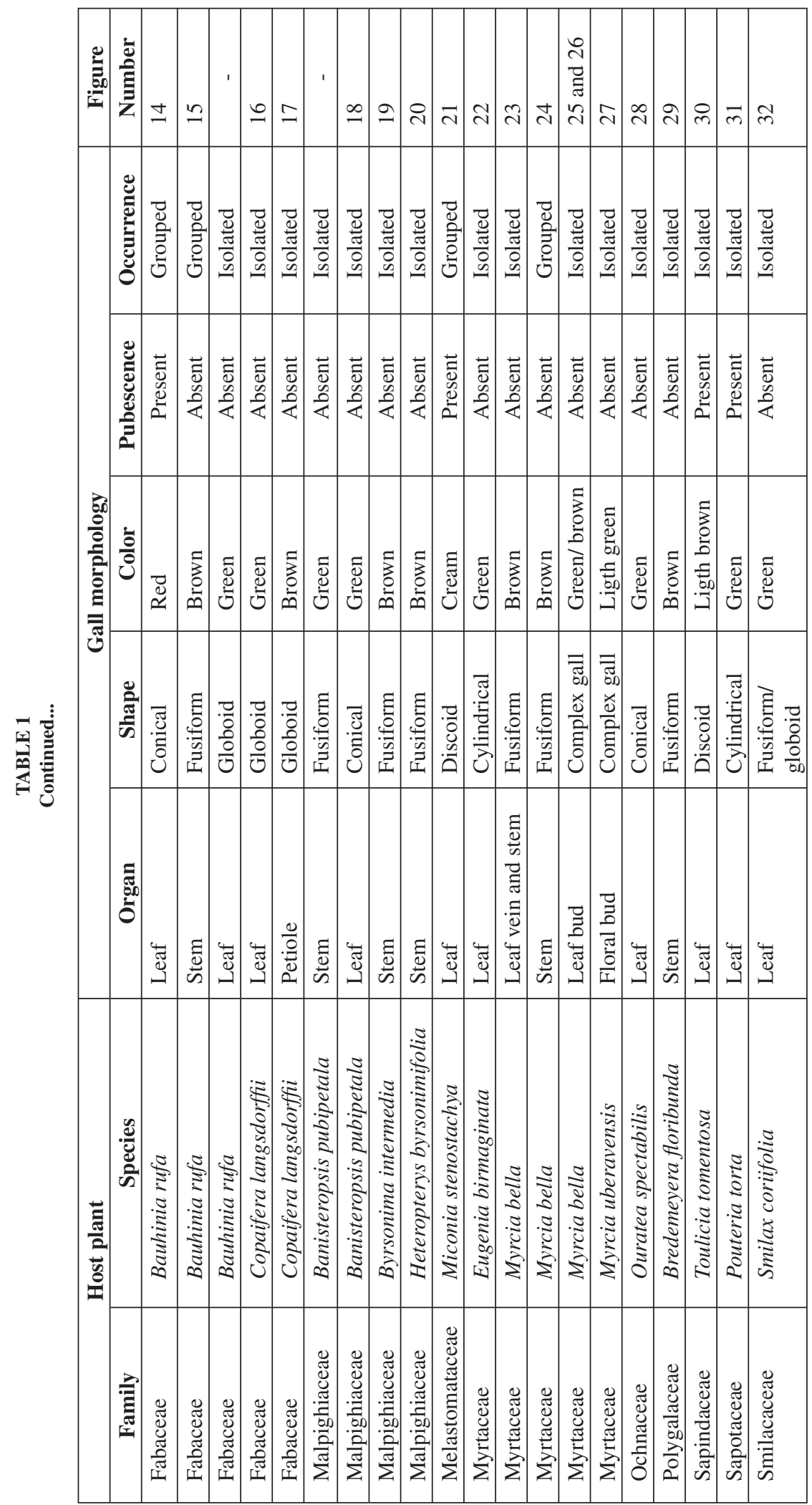




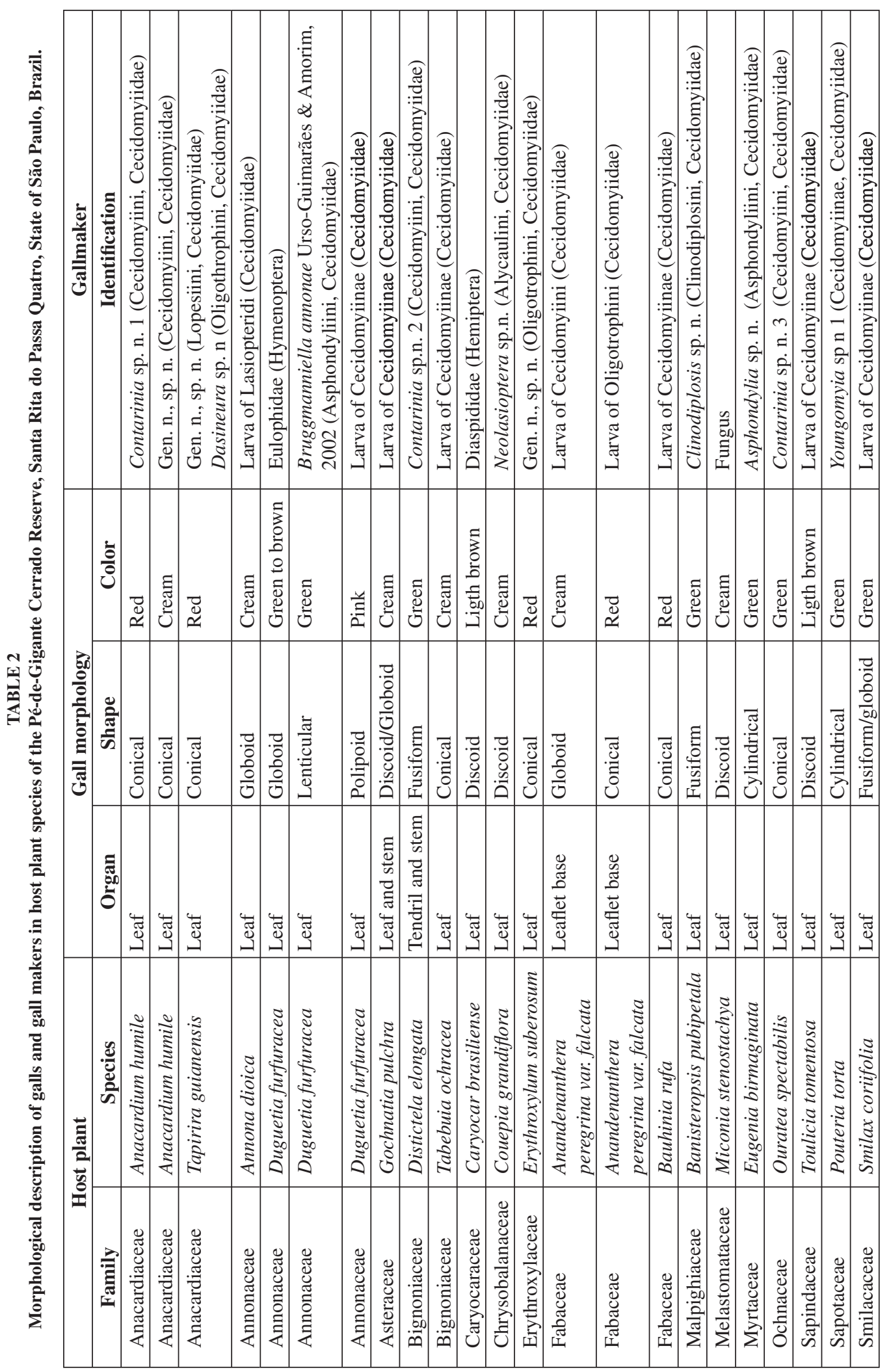



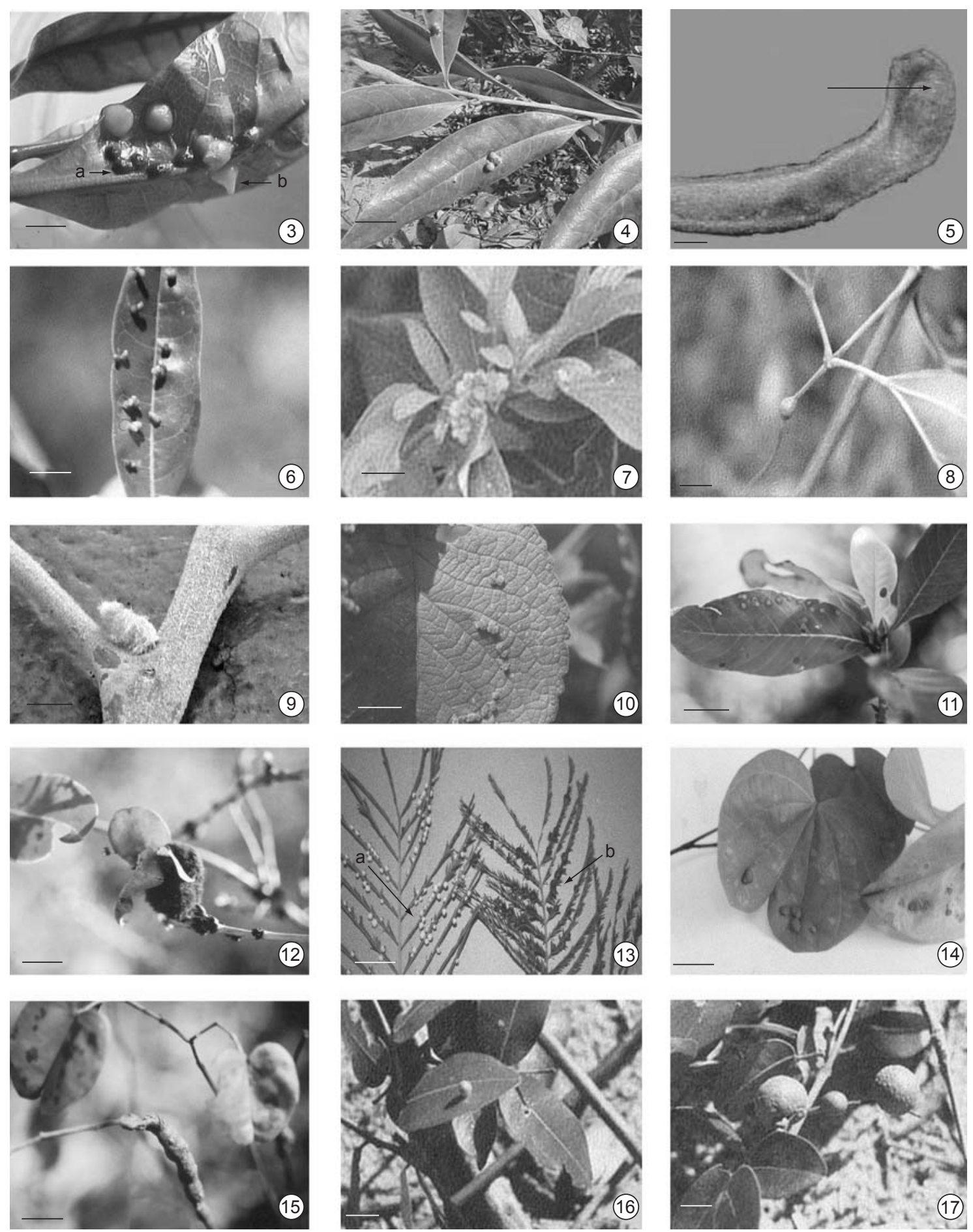

Figs. 3-17 - Galls species of Pé-de-Gigante Cerrado Reserve. 3) Anacardium humile; 4-6) Duguetia furfuraceae; 7) Gochnatia pulchra; 8) Distictela elongata; 9) Tabebuia ochracea; 10) Caryocar brasiliense; 11) Couepia grandiflora; 12)Erythroxylum suberosum;13)Anadenantheraperegrina var.falcata;14-15)Bauhinia rufa; and 16-17) Copaifera langsdorffii. $($ Scale bar $=1 \mathrm{~cm})$. 

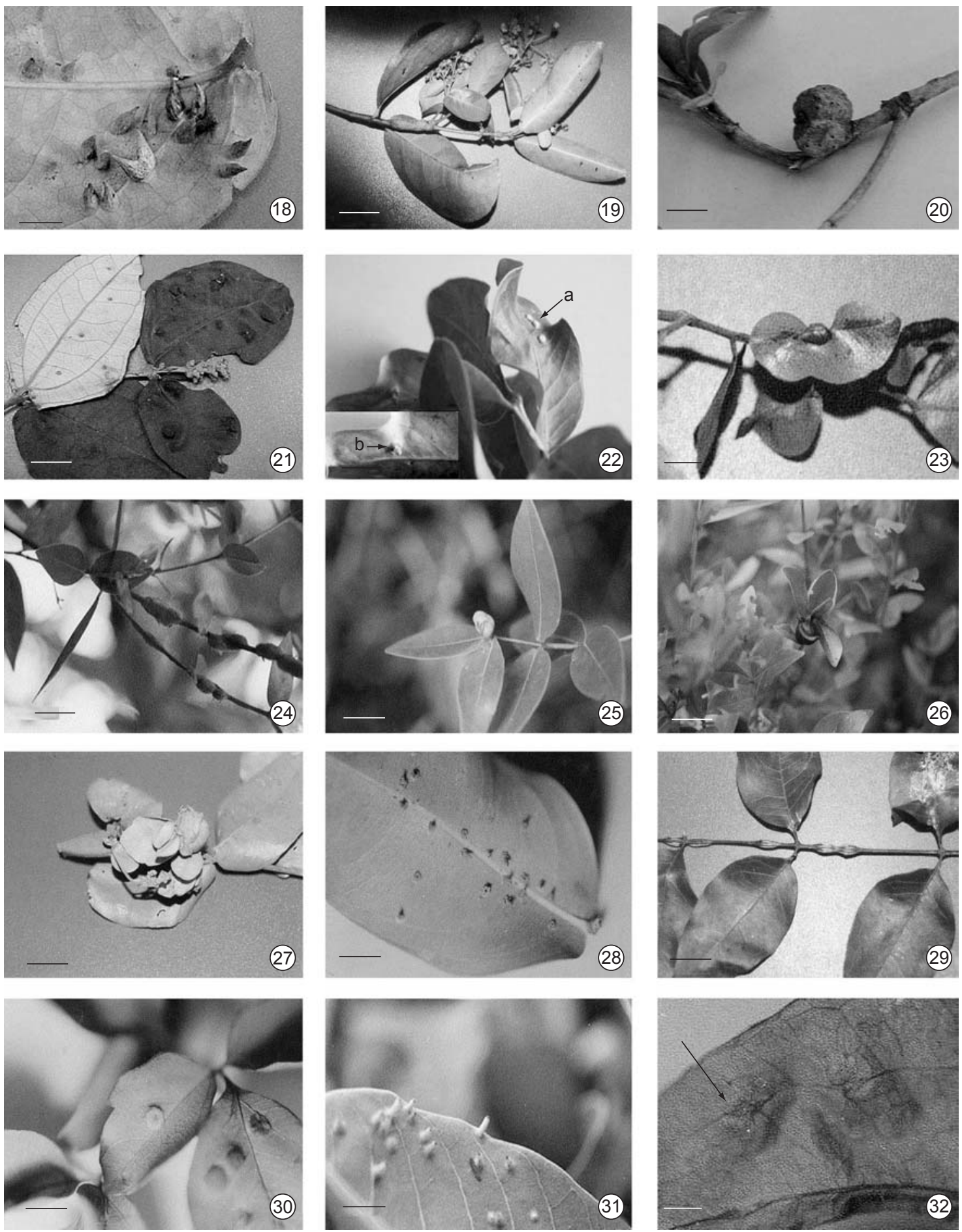

Figs. 18-32 - Galls species of Pé-de-Gigante Cerrado Reserve. 18) Banisteriopsis pubipetala; 19) Byrsonima intermedia; 20) Heteropterys byrsonimifolia; 21) Miconia stenostachya; 22) Eugenia bimarginata; 23-24) Myrcia bella; 25-26) Myrcia bella; 27) Myrcia uberavensis; 28) Ouratea spectabilis; 29) Bredemeyera floribunda; 30) Toulicia tomentosa; and 31) Pouteria torta; 32) Smilax coriifolia (Scale bar $=1 \mathrm{~cm})$. 
Anacardium humile A. St.-Hil. (Fig. 3), Tabebuia ochracea (Cham.) Standl. (Fig. 9), Anadenanthera peregrina (L.) Speg. var. falcata (Benth.) Altschul (Fig. 13) and Copaifera langsdorffii Desf. (Figs. 16, 17) presented two types. The other plant species contained one type of gall.

The galls showed variations in color and appearance, especially during the maturation period, as depicted for the globoid gall of D. furfuracea (Fig. 4), from green to dark gray, and a scaly aspect when mature. In the maturation period, the structures take on stronger shades, as observed in the polypoid leaf gall of $D$. furfuracea (Fig. 6), Copaifera langsdorffii (Figs. 16, 17), in the leaf bud, leaf vein and stem, and petiole galls of M. bella (Figs. 23-26). When young, the globoid gall of $A$. peregrina is pale yellow, and turns red after maturation (Fig. 13a). All the sampled galls belong to the closed type.

Galls of Gochnatia pulchra (Fig. 7), Tabebuia ochracea (Fig. 9), Erythroxylum suberosum A. St.-Hil. (Fig. 12), and Pouteria torta (Mart.) Radlk. (Fig. 31) presented large quantities of trichomes, probably formed as a protection for insects inside the gall. Fernandes et al. (1987) stated that the presence of large quantities of trichomes offers a protective barrier for the inducer's insect larvae against attack by parasitoids and small sucking herbivores that feed on gall tissues.

The distribution of galls in plant organs frequently presented an isolated pattern, which Fernandes et al. (1988) proposed is a protective strategy against natural enemies. The isolated oviposition of the inducer generates isolated galls, forcing parasitoids to spend their energy searching for and using the galls in immature stages.

This is the first report of galls in the following plant genera: Gochnatia (Asteraceae), Distictela (Bignoniaceae), Banisteriopsis (Malpighiaceae), Ouratea (Ochnaceae), and Bredemeyera Polygalaceae).

\section{Gall makers}

One of the most interesting results of this work is the detection of relationships among host plants, gall makers and associated insects, as indicated in Table 2.

Cecidomyiidae (Diptera) are the predominant gall inducers, but inducers were also reared from Eurytomidae (Hymenoptera), Diaspididae
(Hemiptera), and fungus. Trotteria sp. n.1 (Cecidomyiidae, Trotteriini) was found as an inquiline in ex-galls of Youngomyia sp.n. in Pouteria torta. Trotteria also belongs to the family Cecidomyiidae and is traditionally found as an inquiline in ex-galls of Cecidomyiidae in the Neotropical region (Gagné, 1994; Maia, 2001b).

About $95 \%$ the host plant-gall maker relationships reported here are new to science. The relationships reported so far have been Malpighiaceae-Clinodiplosis from Peru described by Gagné (1994), and Pouteria-Youngomyia-Trotteria, whose relationship was reported by Rübsaamen (1916) and Maia (2001b) in a restinga (coastal sandy plains) environment in Rio de Janeiro, Brazil. Tavares (1918) and Houard (1933) also reported galls of Annona sp. induced by cecidomiids, and Fernandes et al. (1988) and Maia (2001a) described galls in Erythroxylum, albeit without providing the plant's specific identification.

The cecidomiids, one of largest families of Diphthera, are little known in Brazil, particularly in areas of open vegetation. As additional results of this study, three new occurrences of genera and thirteen new occurrences of species of the family Cecidomyiidae were identified, and have been described in other papers (Urso-Guimarães \& Amorim, 2005; Urso-Guimarães \& Amorim, submitted). In nine cases, the inducer was collected only in immature stages (larvae), despite five years of diligent sample collecting. These nine types of larvae are from cecidomiids, but specific identification at this level is rarely positive.

The cases in which identification was possible are presented with their diagnostic characteristics. Larvae reared in the creamy gall of Anacardium humile (Fig. 3a) probably belong to a new genus of Cecidomyiini. The larvae do not match the key for immatures of the Nearctic Region genera (Gagné, 1989). Anacardium humile also yielded larvae of Contarinia sp.n.1 in a red gall (Fig. 3b). Contarinia is a cosmopolitan genus whose larval diagnostic characteristic is the presence of a pair of corniform papillae in the terminal segment. The new species has two such papillae.

Specimens of the new genus of Lopesiini were collected in the leaf gall of Tapirira guianensis Aubl. occurring together with larvae of Dasineura. Lopesiini is a tribe with six genera, and the specimens found in this work will be described 
as a new genus based on the separated ovipositor cerci of females. The other Lopesiini have fused cerci. Dasineura belongs to a nonmonophyletic tribe, Oligotrophini (Gagné, 1994), which has nineteen other Neotropical genera. The diagnostic features of Dasineura are clove-shaped larval spatula with six papillae on each side of the spatula and eight terminal papillae in the anal segment. The association with $T$. guianensis is exclusive to this new species.

Specimens of Oligotrophini induce hairy leaf gall in Erythroxylum suberosum (Fig. 12). This is a new genus since the specimens do not match the key to Neotropical cecidomiids (Gagné, 1994).

Specimens of both genera reared in Pouteria torta belong to a new species. The specimens match the description of Youngomyia except for the female's elongated cerci, which are discoid in other species of this genus. The Trotteria species share mid and hind femora successively larger than the fore femur. The new species has tibial spurs, a feature exclusive to this family.

The $9^{\text {th }}$ abdominal segment of the specimens of the new species of Bruggmanniella have a pyriform basal portion, two longitudinal sclerotized dorsal bands, otherwise membranous and striated, and the pupa has a pair of distal projections on the $8^{\text {th }}$ abdominal segment.

The larva of the new Clinodiplosis species has a sclerotized band in the dorsal portion of the thorax, which is exclusive to this species.

As mentioned earlier, the host plant-gall maker relationship is very specific. In the key for the Neotropical Cecidomyiinae, many of the couplets that identify genera are related with the hosts. The species of Asphondylia, Neolasioptera, and the two species of Contarinia were identified as new because this is the first record of these genera, respectively, in galls on Eugenia bimarginata (Myrtaceae), Couepia grandiflora (Chrysobalanaceae), Distictela elongata (Bignoniaceae), and Ouratea spectabilis (Ochnaceae).

Acknowledgments - The authors are grateful for the invaluable assistance of Drs. E. M. Varanda, D. S. Amorim, and S. A. P. Godoy, and to M. I. P. A. Balbi, technician, A. T. Fidelis, biologist, and V. L. Weiser, MSc. (FFCLRP/USP) for their help; to Dr. R. J. Gagné (USDA/Smithsonian Institution); the Instituto Florestal; the Department of Biology/FFCLRP/USP; and the Instituto de Ecología /UNAM, México; and last but not least, to CAPES and FAPESP (Process number 99/01429-1) (Brazil) for conceding the grants.

\section{REFERENCES}

ABRAHAMSON,W.G.\&WEIS,A.E., 1987, Nutritional ecology of arthropod gall makers, pp. 235-258.In:F. Slansky-Junior \& J. G. Rodriquez, (eds.), Nutritional ecology of insects, mites, spiders, and related invertebrates. John Wiley \& Sons, Inc., Publishers, New York, NY.

BATALHA, M. A. \& MANTOVANI, W., 2000, Reproductive phenological patterns of cerrado plant species at the Pé-deGigante Reserve (Santa Rita do Passa Quatro, SP, Brazil): a comparison between the herbaceous and woody floras. Revista Brasileira de Biologia, 60: 129-145.

BATALHA, M. A., 1997, Análise da vegetação da ARIE Cerrado Pé-de-Gigante (Santa Rita do Passa Quatro - SP). Dissertação de Mestrado - Universidade de São Paulo, São Paulo.

BROOKS, D. R. \& MCLENNAN, D. H, 1991, Phylogeny, Ecology, and Behavior. The University of Chicago Press, Chicago. 434p.

FERNANDES, G. W., MARTINS, R. P. \& TAMEIRÃONETO, E., 1987, Food web relationships involving Anadiplosis sp galls (Diptera: Cecidomyiidae) on Machaerium aculeatum (Leguminosae). Revta. Brasil. Bot., 10: 117-123.

FERNANDES, G. W.A., TAMEIRÃONETO, E. \& MARTINS, R. P., 1988, Ocorrência e caracterização de galhas entomógenas na vegetação do Campus Pampulha da Universidade Federal de Minas Gerais. Rev. Bras. Zool., 5: 11-29.

GAGNÉ, R. J., 1989, The plant-feeding gall midges of North America. Cornell University Press, Ithaca, N.Y. 356p.

GAGNÉ, R. J., 1994, The Gall Midges of the Neotropical Region. Cornell University Press, Ithaca, New York. 352p.

HARTLEY, S. E., 1998, The chemical composition of plant galls: are levels of nutrients and secondary compounds controlled by the gall-former? Oecologia, 113: 492-501.

HOUARD, C., 1933, Les Zoocécidies des Plantes de l'Amérique du Sud et de l'Amerique Central. Hermann et Cie, Paris. $519 \mathrm{p}$.

MAIA, V. C., 2001a, New genera and species of gall midges (Diptera: Cecidomyiidae) from three galls of Rio de Janeiro State, Brazil. Revista Brasileira de Zoologia, 18(Supl. 1): $1-32$.

MAIA, V. C., 2001b, Two new species of gall midges (Diptera, Cecidomyiidae) associated with Pouteria caimito var. laurifolia (Sapotaceae) in Brazil. Studia Dipterologica, 8: 103-110.

MANI, M. S., 1964, Ecology of Plant Galls. W. Junk, The Hague, $434 \mathrm{p}$.

PIVELLO, V. R., BITENCOURT, M. D., MESQUITA-JUNIOR, H. N. \& BATALHA, M. A., 1999, Banco de dados em SIG para ecologia aplicada: exemplo do Pé-de-Gigante - SP. Caderno de informação georeferenciadas, 1(3): 1-14.

RÜBSAAMEN, E. H., 1916, Beitrag zur Kenntnis aussereuropäischer Gallmücken, Sitzungsberitche der Gesellschaft Naturforschender Freunde zu Berlin, 1915: 431-481.

SCARELI-SANTOS, C., 2001, Avaliação de sistema galhador-planta hospedeira em ambiente de cerrado: 
aspectos morfo-anatômicos e fitoquímicos. $\mathrm{PhD}$ thesis Universidade Federal de São Carlos - SP. Brazil.

TAVARES, J. S., 1918, Cecidomyias novas do Brazil. Segunda série. Brotéria, Série Zoológica, 16: 69-84, pl. III-IV.

URSO-GUIMARAES, M. V. \& AMORIM, D. S., 2005, Two new species of Bruggmanniella Tavares, 1909 (Diptera:
Cecidomyiidae) from Brazil. Studia dipterologica, Halle (Saale), Alemanha, 11(2): 429-436.

URSO-GUIMARÃES, M. V. \& AMORIM, D. S., submitted, New Brazilian Species of Gall Midges (Diptera: Cecidomyiidae) Associated to Pouteria torta (Sapotaceae). Studia Dipterologica.

\section{APPENDIX}

\section{DATA ON CECIDOMYIIDAE GALLS OR DAMAGE}

\section{Anacardium humile A. St. Hil (Anacardiaceae)}

RN: 169/97, 179/97 (Urso-Guimarães, MV \& Scareli-Santos, C. leg.).

Gall 1 (Fig. 3a). Leaf gall, red, conical, unilocular, larva light yellowish. Gall maker: Contarinia sp. n. 1. Material: larvae. Period of occurrence: October-November.

Gall 2 (Fig. 3b). Leaf gall, white, conical, unilocular, larva white. Gall maker: Gen.n., sp.n. (Cecidomyiini, Cecidomyiidae). Material: larvae. Period of occurrence: October-November.

\section{Tapirira guianensis Aubl. (Anacardiaceae)}

RN: 114/97, 115/97, 132/97, 147/97, 161/97, 198/98, 234/99, 484/2001, 587/2001 (UrsoGuimarães, MV \& Scareli-Santos, C. leg.). Leaf conical gall, red, hairy, unilocular, larva orange and white. Gall maker: Gen. n., sp. n. (Lopesiini, Cecidomyiidae) or Dasineura sp. n. 1. Material: Gen. n., sp. n: females, exuviae and orange larvae, pupation in gall; Dasineura sp. n. 1: white larvae. Period of occurrence: February to November.

\section{Annona dioica A. St.-Hil. (Annonaceae)}

Gall. RN: 01 (Scareli-Santos, C. leg.). Leaf gall, globoid, cream colored, unilocular. Gall maker: unidentified Lasiopteridi (Cecidomyiidae). Material: larvae. Period of occurrence: May.

\section{Duguetia furfuracea (A. St.-Hil.) Benth. \&} Hook. $f$. (Annonaceae)

Gall 1 (Fig. 4). RN: 65a, b/1996, 91/1997, 100/1997, 104/1997, 106/1997, 120/1997, 129/1997, 141/1997, 152/1997, 165/1997, 180/1997, 254/2000, 258/2000, 481/2001 (UrsoGuimarães, MV leg.). Leaf globoid gall, green to brown, unilocular, larva white. Gall maker: Eulophidae (Hymenoptera). Material: adults. Pupation in gall. Period of occurrence: January to December.

Gall2(Fig.5).RN:481/2001(Urso-Guimarães, M. V. \& Scareli-Santos, C. leg.). Leaf gall, lenticular, light brown, unilocular. Gall maker: Bruggmanniella annonae Urso-Guimarães \& Amorim, 2002. Material: exuvia. Pupation in gall. Period of occurrence: March to May.

Gall 3 (Fig. 6). RN: 65c/1996, 255/2000, 481/2001 (Urso-Guimarães, MV \& Scareli-Santos, C. leg.). Leaf gall, polipoid, pink, glabrous, unilocular, larva white. Gall maker: unidentified Cecidomyiinae. Material: larvae. Period of occurrence: March, May, December.

\section{Gochnatia pulchra Cabrera (Asteraceae)}

Gall (Fig. 7). RN: 85/97, 98/97, 101/97, 124/97, 166/97 (Urso-Guimarães, MV \& ScareliSantos, C. leg.). Leaf and stem gall, globoid, totally covered by cream colored trichomes, unilocular, larva cream colored. Gall maker: Cecidomyiidae. Material: larva. Period of occurrence: January, February, October.

\section{Distictella elongata (Vahl) Urb (Bignoniaceae)}

Gall (Fig. 8). RN: 99/97, 127/97, 139/97, 261/2000 (Urso-Guimarães, MV \& Scareli-Santos, C. leg.). Swollen tendril and leaf vein green, glabrous, unilocular, larva cream colored. Gall maker: Contarinia sp.n. 2. Material: adults, exuviae, larva. Pupation in gall. Period of occurrence: January, March, May.

\section{Tabebuia ochracea (Cham.) Standl. (Bignoniaceae)}

Gall (Figs. 9). RN: 126/97, 158/97, 164/97, 168/97, 182/97, 183/97, 267/2000, 574/2001 (Urso-Guimarães, MV \& Scareli-Santos, C. leg.). Stem and leaf galls, conical, with cream colored trichomes, larva cream colored. Gall maker: 
unidentified Cecidomyiinae. Material: larvae. Period of occurrence: March, May, July, September, October, November.

\section{Caryocar brasiliense Cambess (Caryocaraceae)} Gall(Fig.10).RN:263/2000(Urso-Guimarães, MV \& Scareli-Santos, C. leg.). Leaf gall, discoid gall, hairy, light brown, unilocular. Gall maker: Diaspididae (Hemiptera). Material: adults. Period of occurrence: May.

\section{Couepia grandiflora (Mart. \& Zucc.) Benth. ex} Hook. f. (Chrysobalanaceae)

Gall(Fig.11).RN:572/2001(Urso-Guimarães, MV \& Scareli-Santos, C. leg.). Leaf gall, discoid, with cream colored trichomes, isolated, unilocular. Gall maker: Neolasioptera sp. n. Material: larvae. Period of occurrence: September.

\section{Erythroxylum suberosum A. St.-Hil. (Erythroxylaceae)}

Gall (Fig. 12). RN: 116/97, 146/97, 153/97, 162/97, 573/2001 (Urso-Guimarães, MV \& ScareliSantos, C. leg.). Leaf gall, following the principal vein, with red trichomes, multilocular, larva white. Gall maker: Gen.n., sp. n. (Oligotrophini, Cecidomyiidae). Material: adults, exuviae, larvae. Pupation in gall, associated with fungus. Period of occurrence: February, May, July, September.

\section{Anadenanthera peregrina (L.) Speg. var. falcata (Benth.) Altschul (Fabaceae)}

Gall 1 (Fig. 13a). RN: 84/97, 102/1997, 145/1997, 150/1997, 188/98 (Urso-Guimarães, MV \& Scareli-Santos, C. leg.). Leaflet gall, cream colored, globoid glabrous, unilocular, larva white. Gall maker: unidentified Cecidomyiini. Material: larvae. Period of occurrence: January, May, July.

Gall 2 (Fig. 13b). RN: 185/1997, 188/98 (Urso-Guimarães, MV \& Scareli-Santos, C. leg.). Leaflet galls, red, conical with the apical portion tapered, glabrous, unilocular, larva white. Gall maker: unidentified Oligotrophini. Material: larvae. Period of occurrence: March, September, December.

\section{Bauhinia rufa (Bong.) Steud. (Fabaceae)}

Gall 1 (Fig. 14). RN: 67a/1996, 67c/1996, 88/1997, 121/1997 (Urso-Guimarães, MV \& Scareli-Santos, C. leg.). Leaf conical gall, with red trichomes, multilocular. Gall maker: unidentified Cecidomyiinae. Material: larvae. Period of occurrence: December - February.

Gall 2 (Fig. 15). RN: 130/1997 (UrsoGuimarães, MV \& Scareli-Santos, C. leg.). Fusiform stem gall, brown, multilocular. Material: galls. Period of occurrence: March.

\section{Bauhinia rufa (Bong.) Steud.}

Gall 3. RN: 67b/96 (Urso-Guimarães, MV \& Scareli-Santos, C. leg.). Globoid, joining half the leaf, unilocular, Material: galls. Period of occurrence: December.

\section{Copaifera langsdorffii Desf. (Fabaceae)}

RN: 0140/1997 (Urso-Guimarães, MV \& Scareli-Santos, C. leg.).

Gall 1 (Fig. 16). Leaf gall, green, globoid. Material: galls. Period of occurrence: May.

Gall 2 (Fig. 17). Globoid gall, hanging from leaf by a petiole, brown, multilocular. Gall maker: unidentified. Material: galls. Period of occurrence: May.

\section{Banisteriopsis pubipetala (A. Jess.) Cuatrec (Malphighiaceae)}

Gall 1 (Fig. 18). RN: 159/1997, 237/1999, 577/2001 (Urso-Guimarães, MV \& ScareliSantos, C. leg.). Leaf gall green, conical, glabrous. Gall maker: Clinodiplosis sp. n. Material: adults, exuviae, larvae. Period of occurrence: July-September.

Gall 2. RN: 159/1997, 237/1999, 577/2001 (Urso-Guimarães, MV \& Scareli-Santos, C. leg.). Stem gall, green to brown, fusiform, glabrous. Material: galls. Period of occurrence: September.

\section{Byrsonima intermedia A. Juss. (Malphighiaceae)}

Gall (Fig. 19). RN: 70/1996(Urso-Guimarães, MV leg.). Swollen stem, fusiform, brown, glabrous, multilocular. Gall maker: unidentified. Material: larvae. Period of occurrence: December.

\section{Heteropterys byrsonimifolia A. Juss (Malphighiaceae)}

Gall (Fig. 20). RN: 249/99 (Urso-Guimarães, MV \& Scareli-Santos, C. leg.). Swollen stem, fusiform, brown, multilocular. Material: Galls. Period of occurrence: September. 


\section{Miconia stenostachya Schrank \& Mart DC. \\ (Melastomataceae)}

Gall (Fig. 21). RN: 151/1997, 250/1999

(Urso-Guimarães, MV \& Scareli-Santos, C. leg.).

Leaf galls, in groups, discoid cream colored.

Gall maker: fungus. Period of occurrence: July, September.

\section{Eugenia bimaginata A. DC. (Myrtaceae)}

Gall (Fig. 22). RN: 94/1997, 113/1997, 118/1997, 133/1997, 144/1997, 266/2000 (Urso-Guimarães, MV \& Scareli-Santos, C. leg.). Leaf gall, cylindrical, cream colored, unilocular, larva white. Gall maker: Asphondylia sp. n. Material: female, exuviae, larvae. Pupation in gall. Period of occurrence: January to March, May.

\section{Myrcia bella Cambess (Myrtaceae)}

Gall 1 (Fig. 23). RN: 86/1997. Swollen vein leaf and petiole, brown, fusiform, glabrous, unilocular. Material: galls (15.i.1997). Period of occurrence: January.

Gall 2. (Fig. 24). RN: 108/1997, 119/1997, 157/1997, 160/1997 (Urso-Guimarães, MV \& Scareli-Santos, C. leg.). Swollen stem gall, brownish, glabrous, unilocular. Material: galls. Period of occurrence: January, February, July.

Gall 3. (Figs. 25, 26). RN: 92/1997, 260/2000, 482/2001 (Urso-Guimarães, MV \& Scareli-Santos, C. leg.). Complex gall in leaf bud, green, glabrous, multilocular. Material: galls. Period of occurrence: January, May.

\section{Myrcia uberavensis O. Berg. (Myrtaceae)}

Gall (Fig. 27). RN: 87/1997, 110/1997 (Urso-Guimarães, MV \& Scareli-Santos, C. leg.). Swollen of floral bud, green to brown, multilocular, gregarious larvae. Material: galls. Period of occurrence: January.

\section{Ouratea spectabilis (Mart. ex Engl.) Engl. (Ochnaceae)}

Gall (Fig. 28). RN: 236/1999, 583/2001

(Urso-Guimarães, MV \& Scareli-Santos, C. leg.).
Leaf abaxial surface, conical, unilocular. Gall maker: Contarinia sp. n. 3. Material: larvae. Period of occurrence: September.

\section{Bredemeyera floribunda Willd. (Polygalaceae) Gall(Fig.29).RN:241/1999(Urso-Guimarães,} MV \& Scareli-Santos, C. leg.). Swollen stem gall, brown, glabrous, unilocular. Material: Galls (02.ix.1999). Period of occurrence: September.

\section{Toulicia tomentosa Radlk. (Sapindaceae)}

Distribution of plant species in the Neotropical Region: Bolivia, Brazil, Paraguay.

Gall (Fig. 30). RN: 105/1997, 155/1997, (Urso-Guimarães, MV \& Scareli-Santos, C. leg.). Discoid leaf gall, green to brown, with the escape hole in the adaxial surface, unilocular. Gall maker: unidentified Cecidomyiidae. Material: larvae. Period of occurrence: January, June.

\section{Pouteria torta (Mart.) Radlk. (Sapotaceae)}

Gall (Fig. 31). RN: 66/1996, 97/1997, 103/1997, 117/1997, 176/1997, 181/1997, 184/1997, 186/98, 187/98, 189/98, 190/98, 191/98, 192/98, 193/98, 197/1998, 199/1998, 200/1998, 201/1998, 231/99, 233/99, 259/2000 (UrsoGuimarães, MV \& Scareli-Santos, C. leg.). Leaf galls, green, conical, with red trichomes at the tip, larva orange. Gall maker: Youngomyia sp n. Material: adults, pupa, larva of Youngomyia sp n 1. and Trotteria sp n 1 (inquiline). Pupation in gall. Period of occurrence: January to December.

\section{Smilax coriifolia A. DC. (Smilacaceae)}

Gall (Fig. 32). RN: 122/1997, 151/1997, 173/1997 (Urso-Guimarães, MV leg.). Swollen principal leaf vein, light green to brown, fusiform or globoid, glabrous grouped galls, larva white. Gall maker: unidentified Cecidomyiinae. Material: larvae. Period of occurrence: February, July, October. 